\title{
Guido Hinterkeuser Visions of power: Andreas Schlüter's monuments to the Great Elector and Friedrich III and I
}

When Friedrich Wilhelm the Great Elector (the Große Kurfürst, reigned 1640-88) died in 1688, Berlin was under the cultural domination of the Netherlands. ${ }^{1}$ Friedrich Wilhelm had studied in the Netherlands in his youth, and in 1646 married Louise Henriette, a daughter of the Dutch Stadtholder Frederik Hendrik. Relations between the countries were close, and the elector was to visit the Netherlands frequently in later years. The nation was well informed about Dutch art. In 1651 Luise Henriette commissioned a statue of her spouse from François Dieussart (c.160o-61), which was installed in the Lustgarten. ${ }^{2}$ During Friedrich Wilhelm's reign, work by the most outstanding Dutch sculptors arrived in Berlin - among them, besides Dieussart, Artus Quellinus (1609-68) and Bartholomeus Eggers (c.1637-92). ${ }^{3}$ However, by the end of the century the aura surrounding Dutch art had faded. Friedrich III (reigned 1688-1713), aspired to higher things. He wanted Brandenburg's new foreign policy and military strength to find appropriate expression on the diplomatic level, and this could only mean enhancing the dignity of an elector by the dignity of kingship. ${ }^{4}$ The international prerequisites for this were not unfavourable, for in the Duchy of Prussia he ruled a domain that was no longer part of the Holy Roman Empire, and could thus attain the status of a kingdom - unlike the Margravate of Brandenburg.

The way to the crown - finally accomplished in 1701 - was accompanied by an extraordinarily ambitious instrumentalization of politics in art. $^{5}$ When at the start of his reign, Friedrich III wished to commission his own statue from Bartholomeus Eggers, it was because the sculptor - in the service of the Great Elector - had produced statues of his eleven predecessors for the Alabastersaal of his town palace, the Berliner Schloss. ${ }^{6}$ Soon the Dutch connection was not sufficient. The magnetism of ancient and papal Rome and of the France of Louis XIV was stronger. One of the artists brought in for the aggrandisement of Berlin was Andreas Schlüter (1659-1714), appointed sculptor to the court of Brandenburg in 1694. ${ }^{7}$ Schlüter had an unprecedented career in Berlin in his first years there, and was to create two monuments, one posthumously for the Great Elector (fig. 1$)^{8}$ and one for his son, Friedrich III (fig. 12). ${ }^{9}$ In 1698 his post was only court sculptor, yet he was entrusted with the costly and complex reconstruction of the Berliner Schloss. ${ }^{10}$ Today, Schlüter is renowned equally as both a sculptor and an architect.

Andreas Schlüter was born in Danzig in 1659, and trained there as a sculptor in stone. ${ }^{11}$ He may have found a post in the service of the Polish king, Jan III Sobieski, and moved to Warsaw. He might have been involved in the extensions to the royal residence in Wilanów, though to a lesser extent than the relevant scholarship has assumed. Wilanów was a melting pot, where King Jan III Sobieski united artists 
1. Johann Jacobi (1661-1726), after a model by Andreas Schlüter (1659-1714), Friedrich Wilhelm the Great Elector, 1696-1709, bronze and marble, h: $2.9 \mathrm{~m}$ (5.6 m with pedestal). Seen here in its original setting, the Lange Brücke (Kurfürstenbrücke), Berlin. Schloss Charlottenburg, Berlin, Stiftung Preußische Schlösser und Gärten Berlin-Brandenburg. (photo: Brandenburgisches Landesamt für Denkmalpflege und Archäologisches Landesmuseum, Messbildarchiv, Wünsdorf)

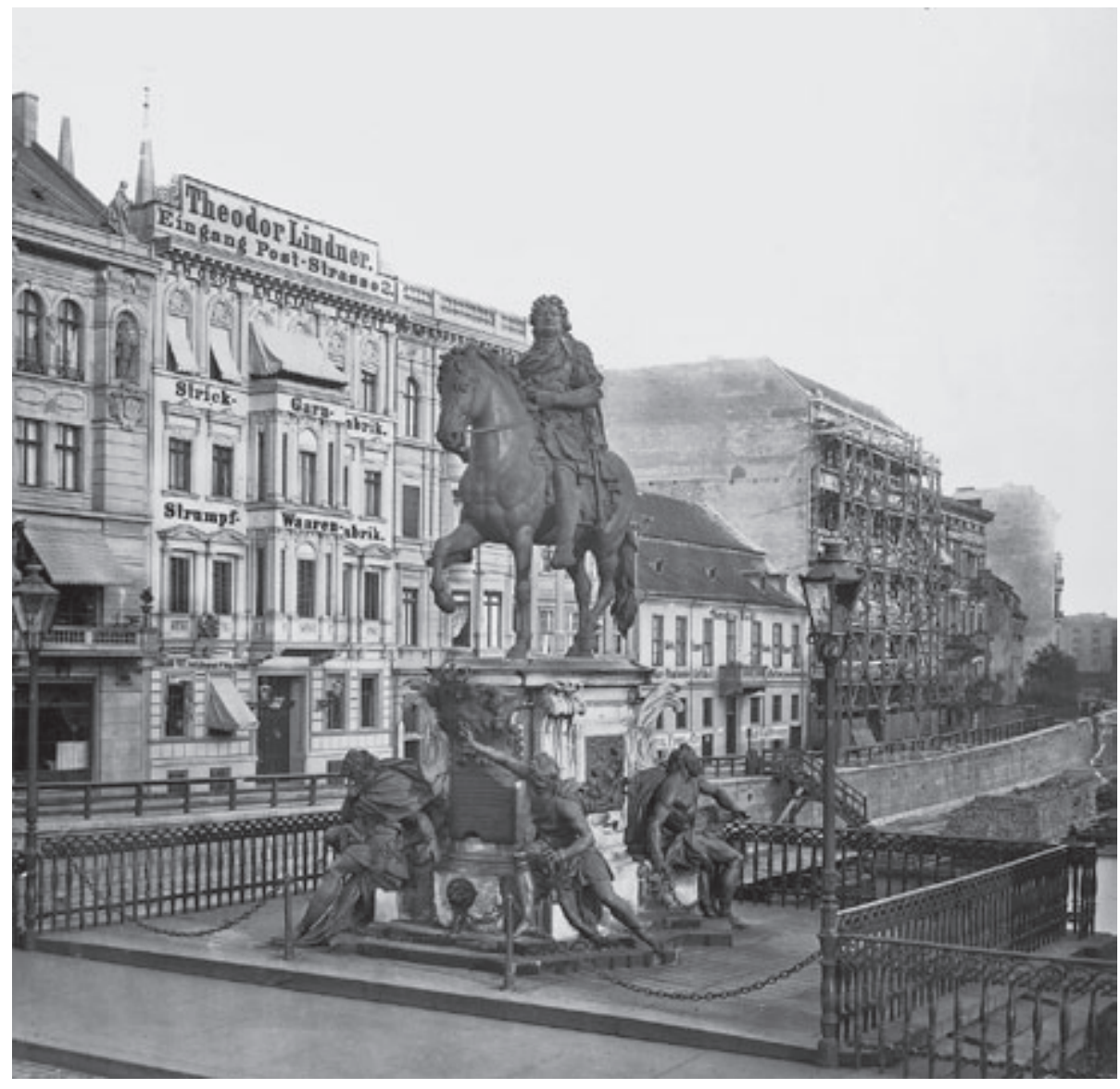

and works of art from many European countries. ${ }^{12}$ Schlüter learnt a great deal there, and encountered an inspiring appreciation of Michelangelo's architecture at the court, where the leading architect, Agostino Locci, referred explicitly to Michelangelo's palaces on the Capitoline Hill. ${ }^{13}$ Schlüter could have made his first visit to Italy during this period. In the early 1690 s he worked on tombs for the Sobieski family, and was commissioned as a sculptor by one of the leading aristocratic families in Poland, the Krasiński, for the building of their new palace in Warsaw.

It seems certain that he was engaged in Berlin for some projects that had already been settled, first and foremost among them the sculpture on the Lange Brücke (Long Bridge), which was then approaching completion. ${ }^{14}$ One of these was an equestrian statue (fig. 1). It says much for the farsightedness of the court that only a few months after Schlüter's arrival, it hired an experienced bronze founder to cast the two monuments. His name was Johann Jacobi (1661-1726), born in (Bad) Homburg. ${ }^{15}$ He had previously worked in Paris in the service of Johann Jacob and Johann Balthasar Keller, ${ }^{16}$ and had experienced at close quarters the casting of the great equestrian statue of Louis XIV on the Place Louis-le-Grand (Place Vendôme). ${ }^{17}$ The only outstanding bronze sculpture in Berlin to date was the tomb of the elector Johann Cicero in Berlin Cathedral, which arrived in Berlin in 1530 from the workshop of Peter Vischer the Elder (c.1460-1529) in Nuremberg. ${ }^{18}$ In a word - there was no tradition of the bronze founder's craft in Berlin. 
2. Jean Baptiste Broebes (c.1660-c.1720), Design for the Schlossplatz. Bird's eye view from the east with the Lange Brücke in the foreground, c.1702, engraving, $32 \times 56 \mathrm{~cm}$.

(photo: Illustration from Jean Baptiste Broebes, Vues des Palais et Maisons de Plaisance, Augsburg 1733, Tab. 1)
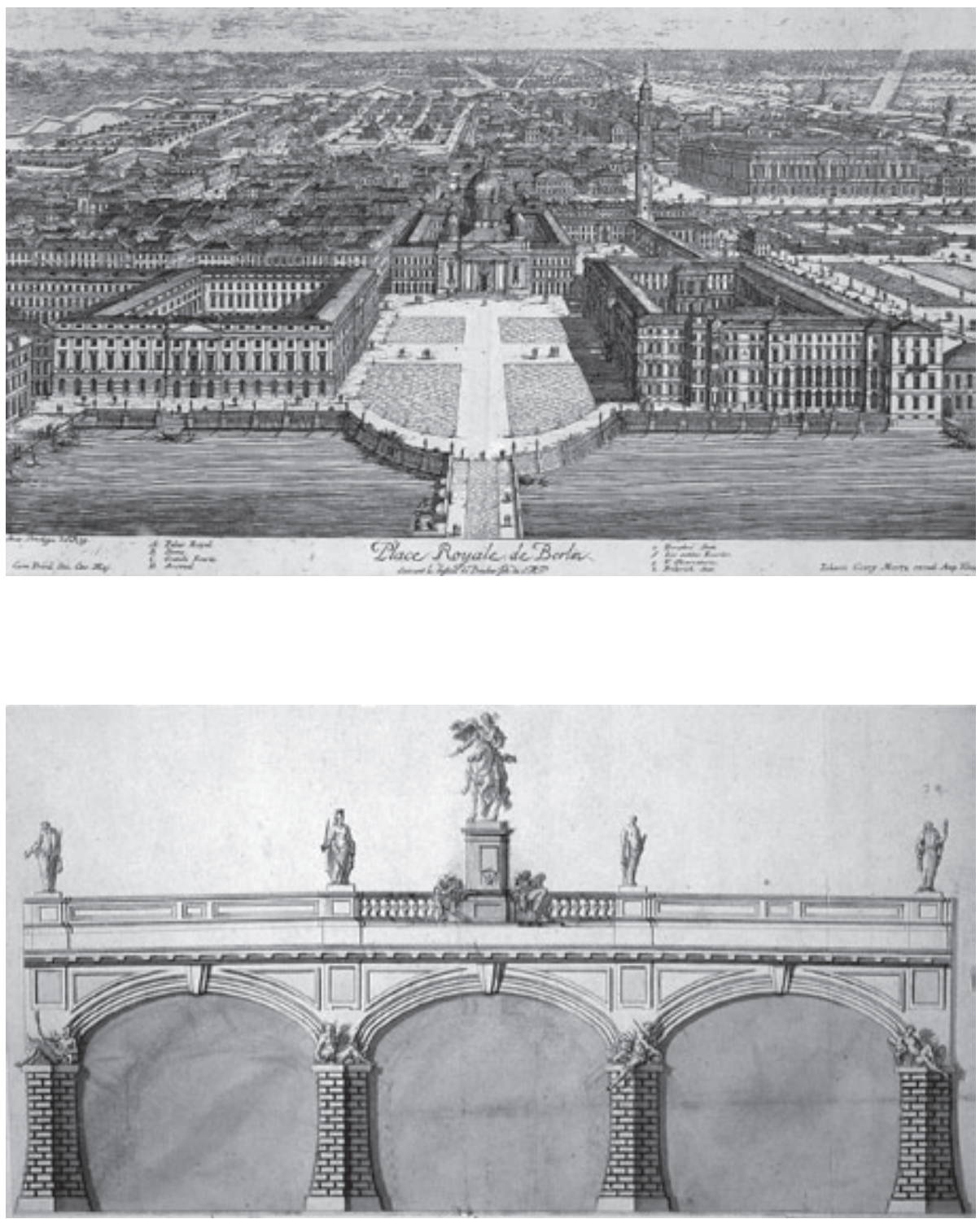

3. Tobias Henry Reetz (16801765), The Lange Brücke in Berlin, with the design of a monument for Friedrich III, before 1697, pen and ink and wash. Gottfried Wilhelm Leibniz Bibliothek - Niedersächsische Landesbibliothek, Hanover. (photo: Bernd Adam)
4. Samuel Blesendorf (1633-1706), View of the Berliner Schloss and the Lange Brücke from the east, 1696, engraving, $9 \times 18 \mathrm{~cm}$.

(photo: Illustration from Lorenz Beger, Thesaurus Brandenburgicus, vol. 1, Cologne/Spree 1696, p. 169)

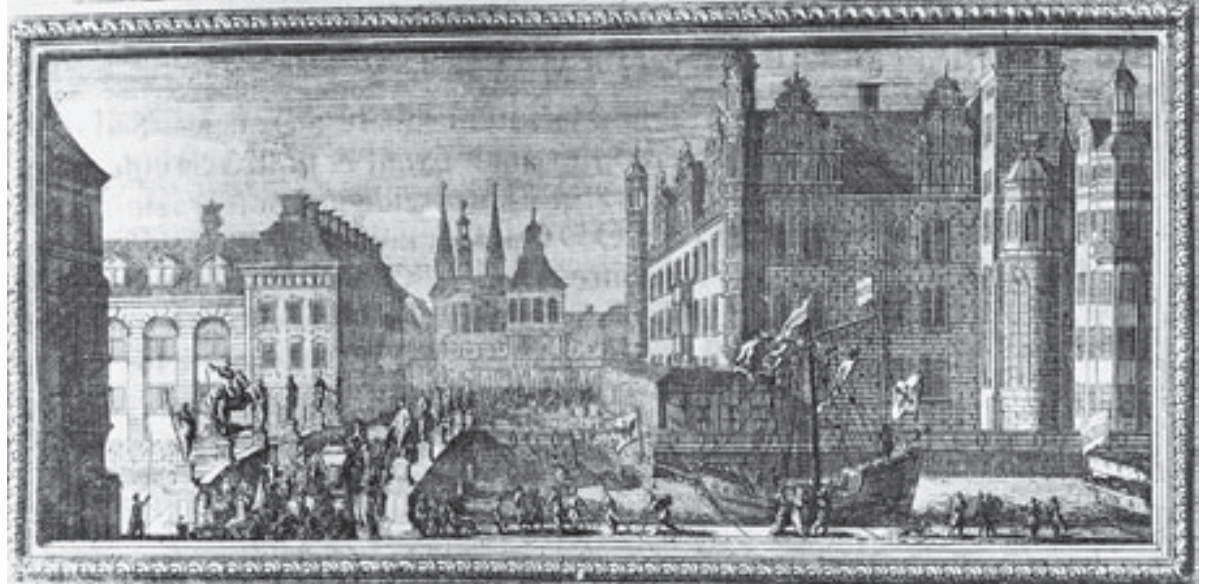

23 | Hinterkeuser: Visions of power 
5. Gottfried Christian Leygebe (1630-83), Friedrich Wilhelm the Great Elector as Saint George, c.1680, cast and chased iron, h: $28 \mathrm{~cm}$. Staatliche Museen zu Berlin Preußischer Kulturbesitz, Skulpturensammlung. (photo: Staatliche Museen zu Berlin Preußischer Kulturbesitz, Skulpturensammlung)

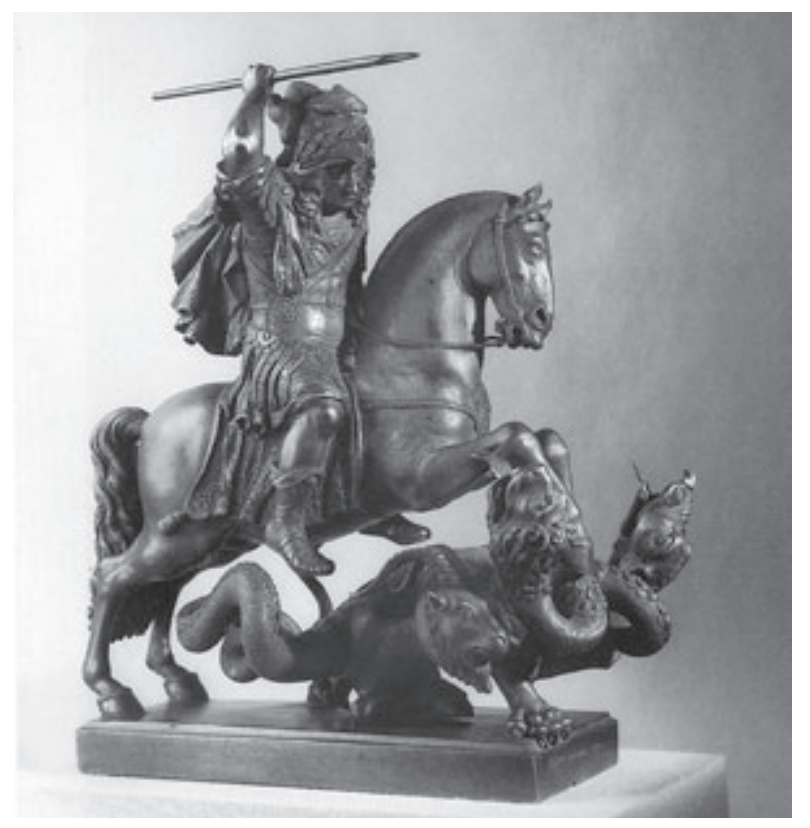

In 1690 the bridge over the Spree was only a plain wooden construction. The Schloss - apart from some selective extensions - was still in every way a building of the sixteenth century, dominated by the aesthetics of the Saxon Renaissance, while the cathedral had medieval associations. Once in office, Friedrich III's ideas for improvements took shape. In 1702 the French architect and engraver Jean-Baptiste Broebes (c.166o-shortly after 1720) submitted an aerial view of a proposed Schlossplatz (fig. 2). This combined the ideas of various artists - some executed and some not - for reconstructing the complex. The Schloss is drawn in at the right as a new building, based on Schlüter's model, and to the right at the rear is the new Zeughaus (arsenal). ${ }^{19}$ The old cathedral was envisaged as a grandiose domed church, a project which never materialized, ${ }^{20}$ any more than the Marstall (royal stables) situated on the left-hand side. ${ }^{21}$ Schlüter did part of the sculptural work on the arsenal, and its courtyard was intended as the location for a statue of Friedrich III. One can recognize a part of the Schloss in a tower about 100 metres high, the so-called Münzturm (Mint Tower), which Schlüter had worked on since $1701{ }^{22}$ Faulty in its construction, its shaky foundations were to cost him his career. In 1706 the tower was practically finished, but it had to be dismantled, and Schlüter was dismissed as architectural director of the building programme.

Broebes' aerial view also shows a stone bridge across the Spree with an equestrian statue at its centre. Ideas for a reconstruction of the Spree bridge and its crowning adornment of an equestrian statue can be traced back to the year 1692. The construction of the bridge, designed by the architect Johann Arnold Nering (1659-95), was begun in the same year, and was fittingly honoured by a medal. ${ }^{23}$ The medal, and a drawing by the young architect Henry Reetz (16801765) dated a little later (fig. 3), ${ }^{24}$ are evidence of the rich sculptural programme planned. River gods of sandstone were envisaged at the foot of the bridge piles, and their execution was among Schlüter's first assignments when he came to Berlin in $1694 .{ }^{25}$ There were plans to place classical gods on the balustrade as symbols of the electoral virtues, on either side of the equestrian statue of the ruler at the centre of the bridge. ${ }^{26}$ However, these plans were later scrapped.

Uncertainty prevailed for some time as to whether the horse was to be rendered trotting or rearing, as in a view from the mid-169os (fig. 4). When work on the equestrian statue at last started in 1696, the painter Paul Carl Leygebe (1664-1730) applied for the commission, and referred to a work in iron by his father Gottfried Christian Leygebe (1630-83) showing the Great Elector as St George, kept in the electoral Kunstkammer (fig. 5) ${ }^{27}$ However, this was not deemed a worthy antecedent for such a major commission, and in any case the protagonists had already been assigned - Schlüter and Jacobi.

For some time Friedrich III was undecided as to whom the equestrian statue should portray: himself the patron - or his father, the Great Elector. The idea 


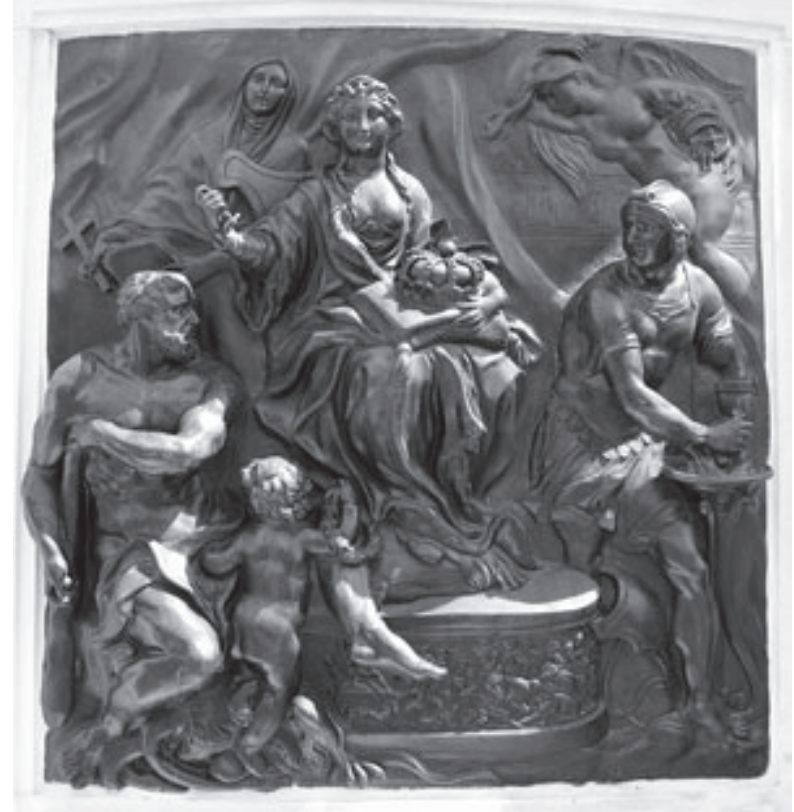

6. Johann Jacobi, after a model by Johann Samuel Nahl (1665-1727), Allegory of the Electorate of Brandenburg, 1708, bronze, c.80 $\times$ $80 \mathrm{~cm}$. On the proper right of the pedestal of the monument to Friedrich Wilhelm, the Great Elector.

(photo: the author)

7. Johann Jacobi, after a model by Johann Hermann Backer (active c.1698-1716), Allegory of the Kingdom of Prussia, 1708, bronze, $c .80 \times 80 \mathrm{~cm}$. On the proper left of the pedestal of the monument to Friedrich Wilhelm, the Great Elector.

(photo: the author)

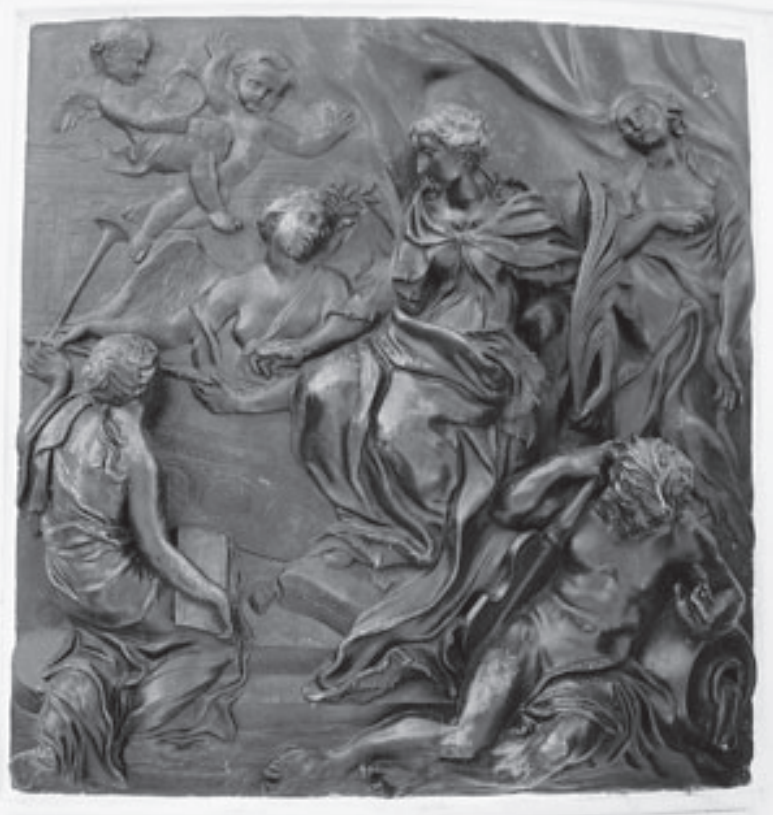

was frequently modified. There had always been talk of an equestrian statue of the Great Elector, even while he was still alive. In 1687 the Swedish architect Nicodemus Tessin the Younger (1654-1728) visited the studio of the Amsterdam sculptor de Jong - probably Hendrick de Jongh (died 1708) - and saw 'a model of wax of the Elector of Brandenburg on horseback with 4 children at the corners of the pedestal, thus representing the 4 winds'. He reported further that 'the horse galloped' and that the 'work was abandoned, because it would have cost over 50,000 thalers. ${ }^{28}$ When at last the execution of an equestrian statue was actually started in the 1690 , Friedrich wanted to be the one on the horse, ${ }^{29}$ but then he dropped the idea and honoured his father instead.

Work began in $1696 .^{30}$ The first delivery of iron for the armature of the large-scale model arrived. This was finished in plaster in August 1697, and the mould was cast in 1698. Probably it was then that a plaster model covered in gold-leaf was erected on the Lange Brücke. It was to stay there as a stop-gap until the completion of the cast - the casting procedure itself was a great spectacle and took place on 2 November 1700 . This, incidentally, was only a day after the death of the last Habsburg monarch of Spain. This is worth mentioning, since the elector profited from the subsequent Wars of Succession - the emperor in Vienna depended on Brandenburg as an ally and could no longer deny him the dignity of kingship. ${ }^{31}$ The treaty with Vienna was signed as early as 16 November 1700; on 17 December the elector set out for Königsberg (now Kaliningrad), where he was to be crowned. Events were coming so thick and fast that by the time he returned to Berlin the new façade of the Schloss had been finished, including a three-bay projection for the entrance reminiscent of a triumphal gate; nevertheless, the plaster stop-gap was still 'trotting' along the Lange Brücke. The chasing and polishing of horse and rider would still take time. At the end of 1701 the king approved the plans for the pedestal. Another year passed before the bronze statue was erected on the Lange Brücke. This was in 1703, on his birthday. Only then did work start on the slaves. We must assume that Schlüter supplied the first designs, while four individual sculptors then worked on the execution of the models. They were cast in 1708. The same year saw the creation of the two side reliefs after designs by the painter Johann Friedrich Wentzel (1670-1729). Finally, in 1709, the inscription panel was completed, as were the volutes on the base, which play a major part in the effect of the whole work. 


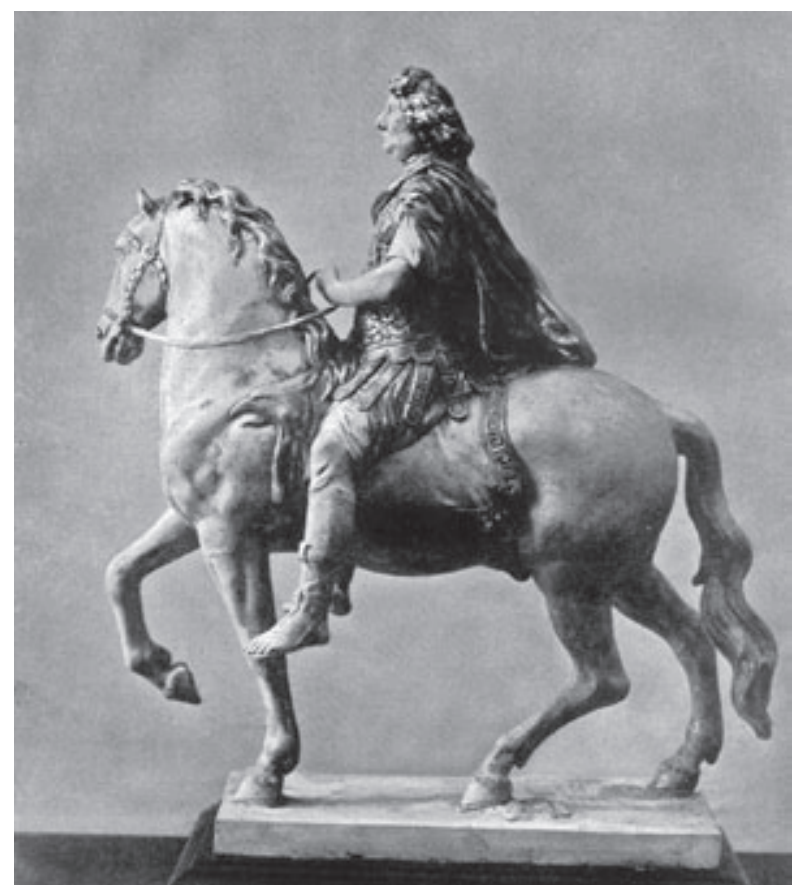

The equestrian statue and the reconstructed Berlin Schloss were the most impressive monuments to the newly acquired status of kingship. Friedrich III, who from now on called himself Friedrich I, honoured not only his father, but himself, through these works. This is manifest particularly on the two reliefs on the base (figs. 6, 7). The proper right shows an allegory of the electorate of Brandenburg, the proper left that of the kingdom of Prussia, thus illustrating the development of the countries under his rule. A medal struck in 1703 on the erection of the statue not only named 'Friedrich the First, August King of Prussia' (FREDERICO I: AVGVSTO BORUSSORVM. REGI), but also mentioned that he had erected this monument to the honour of his father, so that the latter 'would possess eternal glory and as a gesture of piety of his august royal son for the best of fathers' (VT ESSET: AETERNA. GLORIA: ET MAXIMI / FILII: REGIS: IN: OPTIMVM / PATREM PIETATIS

8. Unknown artist, Friedrich Wilhelm the Great Elector, model for a monument, c.1696, plaster, h: $61 \mathrm{~cm}$. Formerly HohenzollernMuseum, Berlin, lost since 1945. (photo: Stiftung Preußische Schlösser und Gärten BerlinBrandenburg, Potsdam)
9. Johann Jacobi, after a model by Andreas Schlüter, Friedrich Wilhelm the Great Elector, 16961709, bronze and marble, h: $2.9 \mathrm{~m}$ ( $5.6 \mathrm{~m}$ with pedestal). Schloss Charlottenburg, Berlin, Stiftung Preußische Schlösser und Gärten Berlin-Brandenburg. (photo: the author)
MONVMENTVM / INSIGNIS). ${ }^{32}$ Honouring his father and not himself was a sign of modesty appropriate to Protestant societies. However, even that solution did not prevent some from thinking that the ceremonies of unveiling the bronze version in 1703 'border[ed] on idolatry', as the secretary of the British envoy wrote in a letter dated 7 July $1703 .{ }^{33}$

The statue is $5.6 \mathrm{~m}$ high including the pedestal and, viewed in detail, consists of a horse and rider produced from one cast, the four slaves, the marble pedestal and its pictorial reliefs and inscription. It is obvious that familiarity with the great tradition of western European equestrian statues infused the design. This had evolved in antiquity and had experienced an enormous boom since the fifteenth century, especially in Italy and France ${ }^{34}$ There were famous models for an equestrian monument on a bridge, such the monument for Henri IV on the Pont Neuf in Paris. ${ }^{35}$ The Berlin monument comes very close to it, particularly the slaves around the base. The deities originally planned for the Berlin bridge also allude to the Ponte S. Angelo in Rome, the former Pons Aelius. ${ }^{36}$ Immediately after its completion in $\mathrm{AD} 134$ ancient divinities were installed upon the balustrade, if we are to believe a coin of the emperor Hadrian. Between 1667 and 1672, the bridge was adorned with ten statues of angels carrying the instruments of the Passion by Bernini. The Lange Brücke in Berlin resonates with Parisian and Roman allusions.

The location of a bridge for the equestrian statue has recently elicited an interpretation of the Great Elector as the legendary hero of Roman virtue, Horatius Cocles. ${ }^{37}$ This is unlikely, notwithstanding Friedrich III's possession of a Roman coin depicting an equestrian monument on a bridge, which was published in the second volume of the Thesaurus Brandenburgicus. ${ }^{38} \mathrm{~A}$ Roman publication from the first half of the seventeenth century did interpret this coin as representing a monument for Horatius Cocles on the Pons sublicius, ${ }^{39}$ although historically speaking it refers to an honorary statue for the consul 


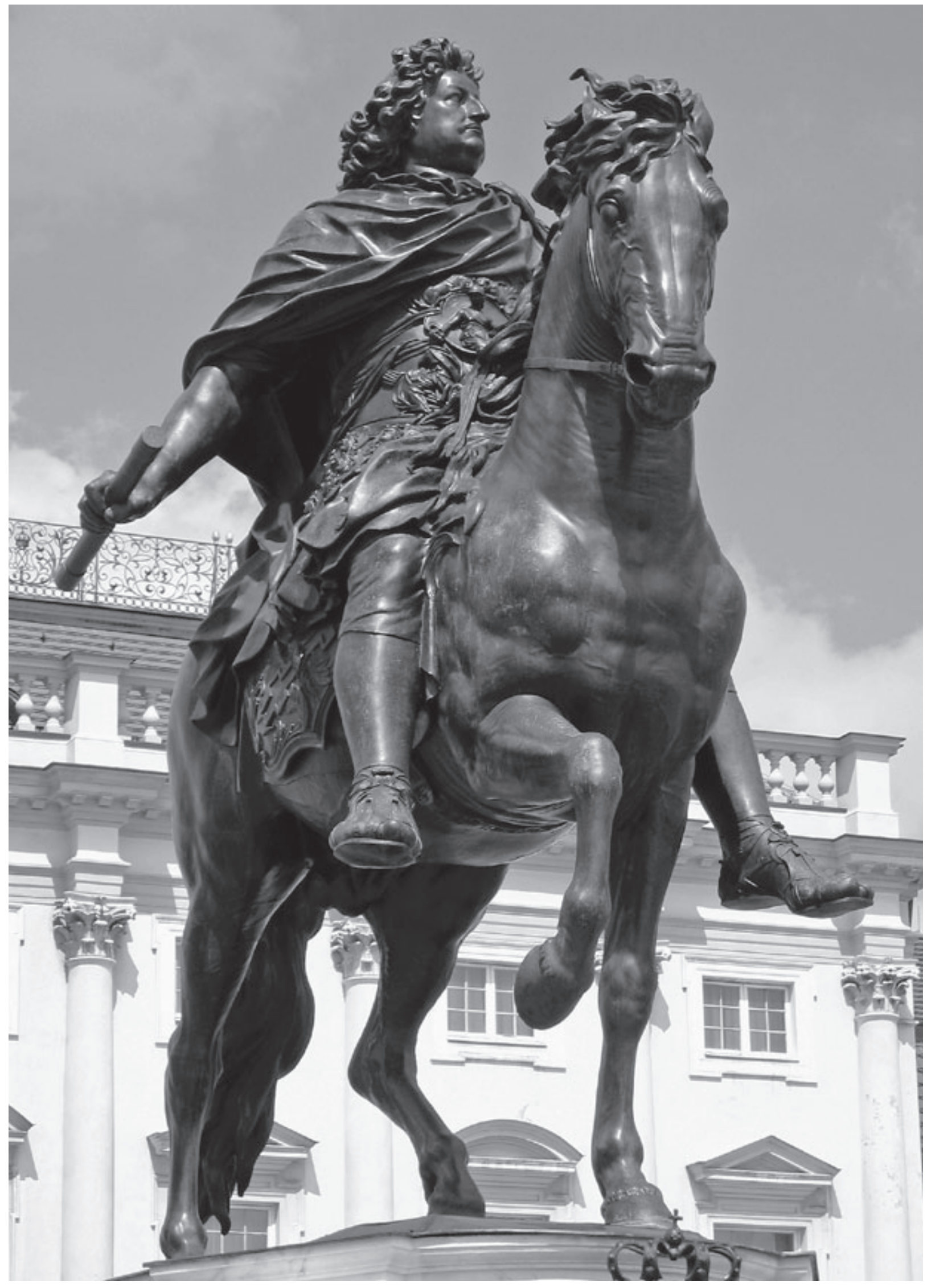


Quintus Marcius Tremulus. ${ }^{40}$ However, this reading is not accepted in the detailed description in the Thesaurus Brandenburgicus. And even if the planners had wanted to establish an association with Horatius Cocles, they would have certainly cast a quick look at the original text by Livy ${ }^{41}$ and realized that the Roman hero, the defender of Rome against the Etruscans in $507 \mathrm{BC}$, was hardly suitable as an actual model. Firstly, the Pons sublicius - as the name suggests - was a wooden pile bridge, since in time of danger, a stone bridge could not be broken up speedily enough. In Berlin a stone bridge had at last replaced the wooden bridge which had spanned the Spree for centuries, and had been last renovated in 1661. Cocles' achievement consisted in defending the Pons sublicius against the Etruscans until the Romans broke it up: not an apposite allusion for a new stone bridge, with its associations of permanence and stability. Further, Livy states that Cocles received a monument in gratitude on the Forum Romanum, not on the Pons sublicius. One final remark: if the planners had wanted to allude to Horatius Cocles, there would have been at least one opportunity to proclaim this unambiguously, namely on one of the two aforementioned reliefs on the base of the equestrian statue. A component of the allegory of the Electorate of Brandenburg is represented by Mucius Scaevola, a symbol of patriotism, who had distinguished himself just one year before Horatius Cocles in the same campaign against the Etruscans.

In Berlin, the horse and rider of the equestrian monument were created under the direct influence of François Girardon's (1628-1715) equestrian statue of Louis XIV on the Place Louis-le-Grand (Place Vendôme) in Paris..$^{42}$ This was cast in 1692, but had not yet been erected in 1696, when work was started on the equestrian monument in Berlin. Exact information about the project was, however, available, especially if we remember that Jacobi took part in the casting process. It is possible that Schlüter had been to Paris prior to this, and was acquainted with the work and its development. ${ }^{43}$ Girardon shows the king in Roman ceremonial armour with a billowing cloak, half-length leggings and strapped sandals, armed only with the royal sword. The arm, in a gesture based on the equestrian statue of Marcus Aurelius on the Capitol in Rome, commands and blesses at the same time. The relaxed nature of the sovereign posture, and the proud glance of the slightly turned head, present Louis XIV as the ideal archetype of the absolute monarch.

In principle, the Berlin monument keeps to the Parisian scheme, as we can see in the preliminary model (fig. 8). ${ }^{44}$ The Roman uniform suggests timelessness. By dispensing with contemporary authenticity, one could avoid being out of fashion within the space of a generation, thereby losing the link to universality. So the Great Elector is portrayed as a Roman emperor, in armour (cuirass) and cloak, with the characteristic laminae protecting the abdomen, and wearing sandals. One concession to the present is the allonge wig, as in the case of Louis XIV.

The unity of Schlüter's design was a constant source of admiration in later art historical literature. Although Schlüter assimilated many international influences in his statue, the result is not eclectic. He succeeded in subordinating everything to one idiom, his own idiom, an idiom that is infused throughout by a dynamic energy. While the view from the west can be called the 'pacific' aspect (fig. 1), indicating the peace-loving and mild sovereign, the other is seen as the warlike side (fig. 9) ${ }^{45}$ Not the least of the Great Elector's attributes was his status as a great 


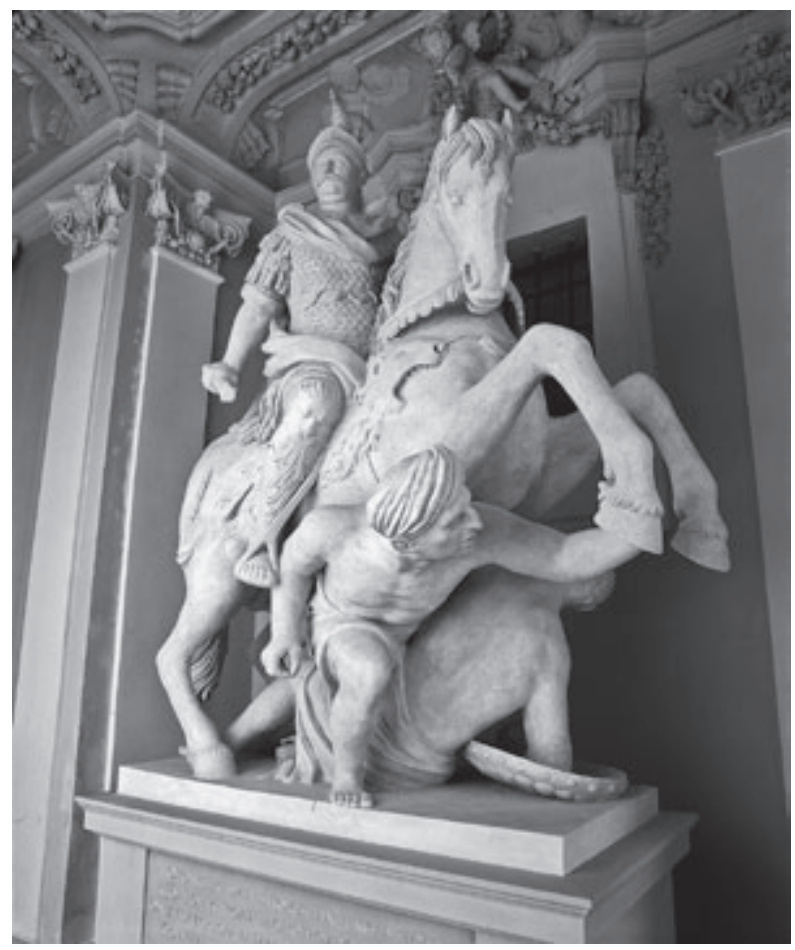

10. Unknown artist, Jan III Sobieski, end of seventeenth century with later additions, plaster, $290 \times 236 \times 125 \mathrm{~cm}$. Palace Museum, Wilanów. (photo: Z. Reszka) general. At the battle of Fehrbellin in 1675 he had annihilated the Swedish troops, decisively enhancing the basis for the future grandeur and aura of the Brandenburg-Prussian state. The victory brought him much prestige throughout the Reich, as the Swedes had previously been thought invincible. Thus the elector's appearance is far more dynamic on this side. Cloak, leggings and hair of horse and rider stream in the wind. It distinguishes the monument from many of its predecessors in which stilted ceremony predominated and one has the impression that horse and rider hover in a vacuum. Here, horse and rider truly form a unity. Here, too, there is a striking difference to many other equestrian monuments, in which the rider is frequently rendered as overdimensional and seated stiffly upon the horse. Schlüter unifies the movements of horse and rider, underscoring this to a great extent by the diagonal from horse's mane to rider's leggings.

Research has long recognized that Schlüter's composition of the warlike side of his equestrian statue shows striking parallels to Francesco Mochi's (1580-1648) equestrian statues for Alessandro and Ranuccio Farnese in Piacenza, made in $1634 .{ }^{46}$ Both express power and dynamism, the drag of the wind being felt in every detail, transported through the self-assured and imperial forward-striding momentum of the figures. But another possible model has been overlooked: a plaster model of an equestrian monument to King Jan III Sobieski (Wilanów Palace, Warsaw) (fig. 10), although we have no exact knowledge of how precisely later additions and repairs kept to the original. ${ }^{47}$ If the monument was completed before Schlüter left Warsaw, he must have seen it, perhaps even participating in its creation in some way or other. Despite the different type here the horse is rearing - there are obvious elements in common with the Berlin monument: for instance the sovereign's calm, sweeping glance into the distance, the secure, firm grip of the commander's baton, and - not least - a small detail: the design of the saddle cloth with eagle and lion heads, respectively.

The same is true as regards the characteristic composition of the slaves at the foot of Schlüter's monument, which not only constitute an essential element in the dynamism of the total design, but also serve to enhance the sublime nature of the ruler. ${ }^{48}$ The left slave, for instance, reveals familiarity with Michelangelo's Pensieroso in the Medici Chapel in Florence, while the right shows the influence of the Laocoon group and Bernini's Four Rivers fountain. The art historian Albert Brinckmann put his finger on Schlüter's response to the European tradition as early as the 1920s: Viele Einflüsse - geniale Synthese! ('Multiple influences - genius in synthesis!') $)^{49}$

When Friedrich I died in 1713 after ruling for twenty-five years, he had achieved a great deal. He had secured the royal throne for his house, an important foundation for the further ascent of Prussia in the eighteenth and nineteenth 


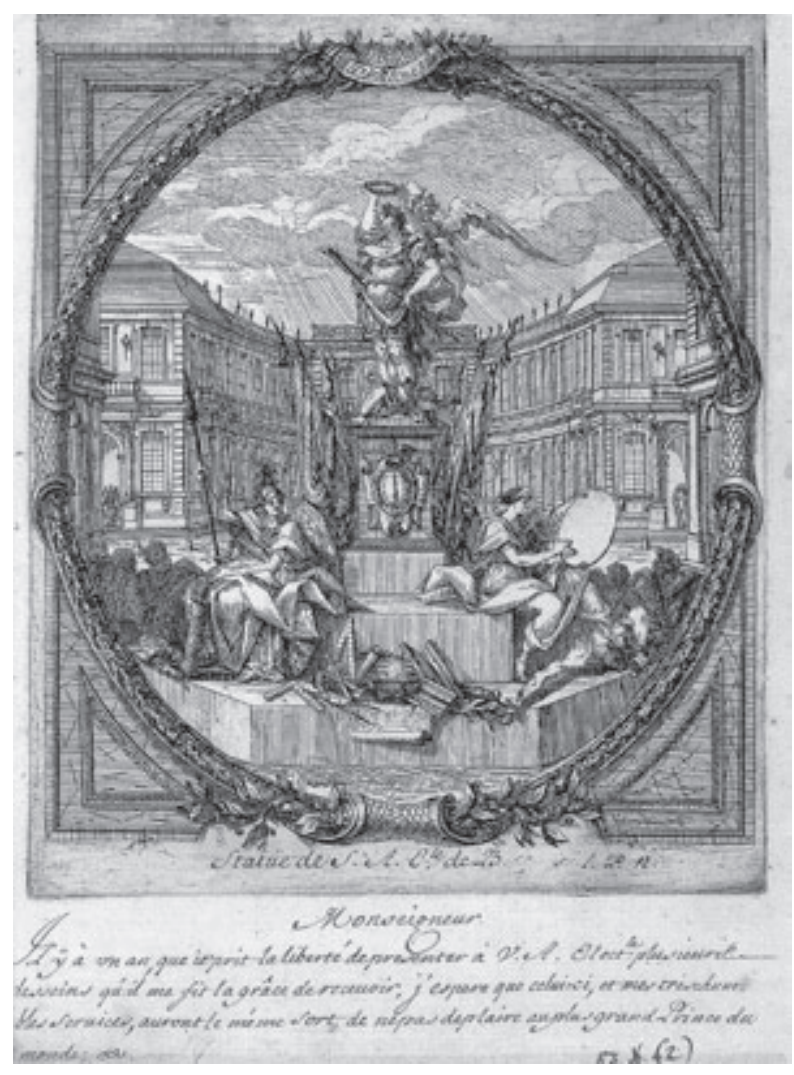

centuries. The Renaissance palace in the city had advanced to become the most modern residence in the Holy Roman Empire, and had no need to fight shy of international comparison, for instance with the reconstruction and amplification of the Louvre and Versailles, or the building of the Stockholm palace. ${ }^{50}$ He had erected a prominent monument to his father which was to be the emblem of Berlin for a long time to come: the monument did in fact become a symbol of the Prussian state, for the fall of Prussia also affected the traditional position of the monument. In 1943 it was moved from its place on the Lange Brücke and stands today in the courtyard of Schloss Charlottenburg.

At Friedrich's death, Schlüter made the model for his sarcophagus, which Johann Jacobi cast in tin and lead. It became the counterpart of the sarcophagus for Queen Sophie Charlotte that both had created in $1705 \cdot{ }^{51}$ But let us now turn to the monument to Friedrich. ${ }^{52}$ It had a peculiar fate, considering that for a time Friedrich wanted a perpetual monument to his memory on the Lange Brücke. In 1692 Broebes submitted what seemed an opportune design for a

11. Jean Baptiste Broebes, Design of a monument for Friedrich III, 1692, engraving, $24 \times 19 \mathrm{~cm}$. Landesarchiv, Berlin. (photo: Landesarchiv, Berlin) statue of Friedrich III, which - according to handwritten addenda - he wished to erect on the Lange Brücke (fig. 11)..$^{53}$ There is a striking resemblance to the Louis XIV statue on the Place des Victoires created by Martin Desjardins (1637-94) between 1679 and 1686, not least in the figure of Fame flanking it. ${ }^{54}$ At the latest in 1696, however, it was clear that two different monuments were needed, first the equestrian statue for the Great Elector, and secondly, a statue for Friedrich III. The latter was finished in 1698 (fig. 12). Schlüter had made the model, Jacobi supplied the cast.

The statue was to be erected in the inner courtyard of the Berlin Zeughaus, which was as we have seen then in the planning stages. ${ }^{55}$ As with the Lange Brücke, Schlüter was at first expected to make the sculptural adornment. Among the outstanding works here - they are among Schlüter's masterpieces - are the masks of dying warriors. ${ }^{56}$ They were to have lined the courtyard, with the bronze sculpture installed in the centre. This was never accomplished; construction on the Zeughaus was delayed, and no one wanted to place the monument on a building site. Moreover, the elector had little interest in it later, since it did not have any royal insignia. The royal sceptre was only added long after his death. Under his son, Friedrich Wilhelm I, the idea was mooted of placing the monument on a column, but this never progressed further than the initial stages.$^{57}$ Finally, on the centennial of the coronation in 1801 , it was sent to Königsberg, ${ }^{58}$ where it was lost in 1945 after Soviet troops took the city. The monument is a poignant symbol of the rise and fall of the Prussian state. Luckily, full-size plaster casts - made in the nineteenth century - have been preserved. 
12. Johann Jacobi, after a model by Andreas Schlüter, Friedrich III, 1697-98, bronze, h: $2.13 \mathrm{~m}$. Formerly Königsberg, lost since 1945.

(photo: Brandenburgisches Landesamt für Denkmalpflege und Archäologisches Landesmuseum, Messbildarchiv, Wünsdorf)
Portraying the sovereign in the garb of a classical emperor was usual. Contemporary attire such as that on a life-size wax image of the elector in the Berlin Kunstkammer (fig. 13$)^{59}$ may have been thought too indecorous for a public monument. There is, however, contemporary evidence that such attire might have been an option. ${ }^{60}$ Concerning costume, the court followed French models, such as the statues of Louis XIV by Desjardins or Antoine Coyzevox (1640-1720). ${ }^{61}$ Schlüter's statue of Friedrich III reveals yet again his predilection for dynamic composition. Here, too, the figure is caught by the wind; the elector seems just to have taken a stride forward. His facial expression is a manifestation of willpower. Capturing personality in this way, combining a mimetic rendering of the true personality with ideal enhancement, is again Schlüter's very personal accomplishment, as was his response to a famous model from antiquity, the Apollo Belvedere, which, as his contemporaries saw, was his inspiration for the portrait of Friedrich. $^{62}$

What Schlüter and Jacobi accomplished was the result of blending numerous conceptual specifications with their own individual creative powers. Both monuments involved complicated planning and building processes that went back much further than the time of Schlüter's and Jacobi's arrival in Berlin. Schlüter did not arrive in Berlin as an all-powerful impresario. It is interesting to see how he fulfilled his commissions, and yet accomplished things over and above these that his patrons in no way expected. This 'added value' was the secret of Schlüter's mastery, which art history started to admire from the second half of the eighteenth century. At the time, however, in the decades directly after the erection of the monuments, it seems that more attention was given to Johann Jacobi and his success in casting the equestrian monument in one piece. ${ }^{63}$

The accompanying text to Johann Georg Wolfgang's presentation engraving of the equestrian monument (fig. 14), published after 1704, mentions both artists on equal terms: 'Fusa est ex ære alt. ped. XV. pond. libr. CXXVIII, summa cura \& unico eoque felicissimo jactu à Johanne Jacobi Fusore Regis Boruss. ad exemplar a Slutero ejusque Reg. Architect. ac Statuario perfectissime elaboratum. ${ }^{, 64}$ But comment on the equestrian statue that followed in the first half of the eighteenth century devoted more attention to Jacobi than to Schlüter. The technical achievement of producing horse and rider in a single cast yielded higher prestige and acclaim than the creation of the model. Thus, to quote Schramm in 1735:

The first model of this statue was made by the Oberbau Director, Schlüter, and was cast thereafter, happily in one piece, by the famous Johann Jacobi born in Hamburg in Hesse, a man 
13. Unknown artist, Friedrich III, before 1699, wax and materials, life-size. Formerly HohenzollernMuseum, Berlin, lost since 1945. (photo: Stiftung Preußische Schlösser und Gärten BerlinBrandenburg, Potsdam) most experienced in the art of casting, and as we can see, finished with the most refined embellishments. Both because of this and because of other fine pieces cast in this way, His Most Serene Late Majesty commissioned at royal expense a beautiful golden chain, and on it a medal with his portrait, together with the Statua equestra and slaves, engraved in copper by the Royal Engraver, the renowned Johann George Wolfgang. ${ }^{65}$

In 1756 Johann Christoph Müller and Georg Gottfried Küster said much the same, and quoted two poems which praised Jacobi's achievement alone and did not even mention Schlüter. ${ }^{66}$

Similarly, travellers' guidebooks name only Jacobi and are silent about Schlüter's role. When Carl Christian Schramm had to shorten his gazetteer of bridges written in 1735, and republished in his encyclopaedia of travel 1744, he decided to leave out Schlüter's name: 'the equestrian statue of the Elector Friderich Wilhelm the Great [was] cast by the Director of the Prussian Royal Foundry, J. Jacobi'. ${ }^{67}$ A letter of 1731 declared 'this magnificent monument of metal was made by a famous artist Jacobsen born in Switzerland and is regarded by all connoisseurs as a very great artistic masterpiece of this kind'. ${ }^{68}$

Only when the early historiography of art in Berlin gained momentum in the mid-eighteenth century was Schlüter's achievement duly appreciated. The inspired creator of the model from then on enjoyed higher esteem than the man who cast it - and this has never changed. In an early art dictionary of 1768 , Jacobi did not receive a single entry, and in the article on Schlüter he is only mentioned as a founder of cannons. ${ }^{69}$ It was Friedrich Nicolai who finally 'rediscovered' Andreas Schlüter and promoted him as a hero of Berlin's history and art. In a short article in his Lives of Berlin Artists, he names Jacobi as a 'very skilful bronzefounder' and describes his collaboration with Schlüter. ${ }^{70}$ Schlüter's oeuvre is then prized in paeans of praise extending over several pages. Nicolai described the equestrian statue as 'his masterpiece, which alone would merit immortality for the artist'. ${ }^{71}$ He left no doubt that Schlüter's work did not always receive its due acclaim, but was convinced at the same time that his work, both in architecture and sculpture, would eventually assert itself:

But his immortal works, which beautify Berlin, stand here: silent witnesses defying the slander of his contemporaries, incontrovertible proofs of the talents of an artist of the first rank, whom few can rival and even fewer surpass, and whose steadfast emulation shall never be the work of a commonplace mind. ${ }^{72}$

Today, art historiography prefers to interpret the bronze monuments of the Great Elector and his son, Friedrich III and I, as the joint effort of Schlüter and Jacobi; the perfectionism of the one turned the work 


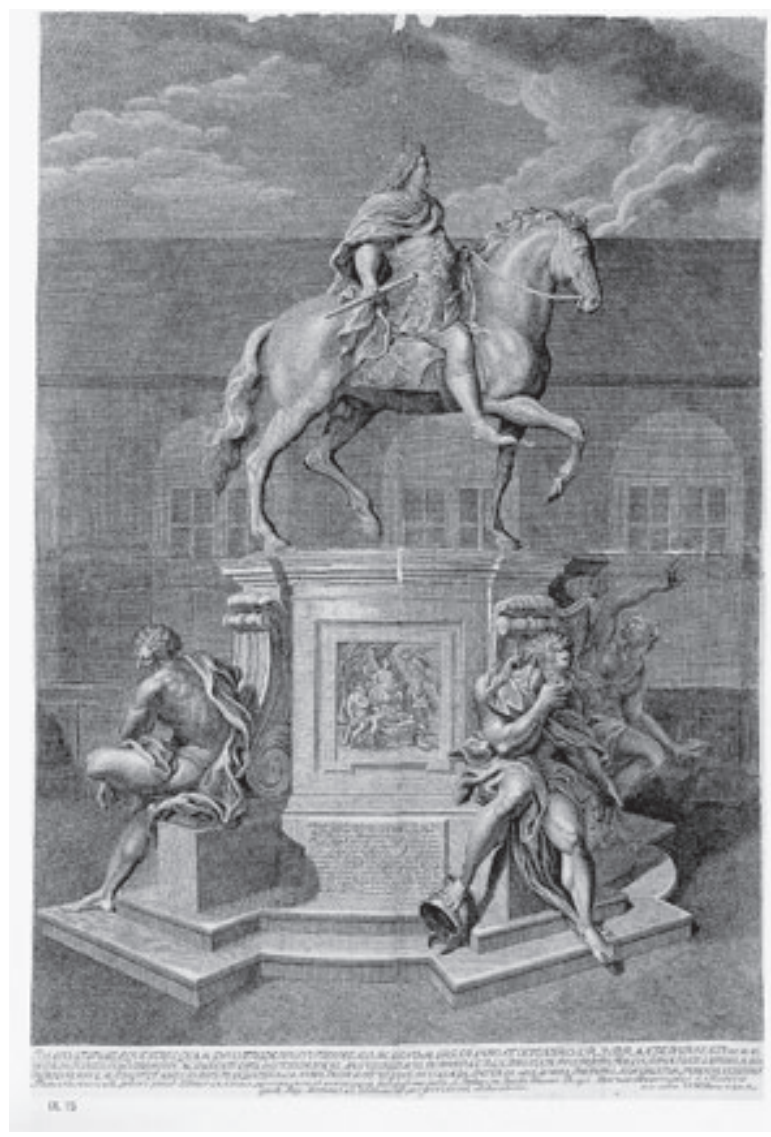

14. Johann Georg Wolfgang (1662-1744), Monument of Friedrich Wilhelm the Great Elector, c.1710, engraving, $101 \times$ $67 \mathrm{~cm}$. Staatsbibliothek zu Berlin Preußischer Kulturbesitz, Kartenabteilung. (photo: Staatsbibliothek zu Berlin Preußischer Kulturbesitz Kartenabteilung)

This article is based on a paper given at the international conference 'Sculpted Portraits of Rulers and Royalty from Conrat Meit to Canova', Wallace Collection, London, 2-3 July 2004. I want to express my deepest gratitude to Léon E. Lock (Leuven), Abigail Ryan-Prohaska (Berlin) and Christian Theuerkauff (Berlin). 1 P. Seidel, 'Die Beziehungen des Großen Kurfürsten und König Friedrichs I. zur niederländischen Kunst', Jahrbuch der Königlich Preußischen Kunstsammlungen, 11, 189o, pp. 119-49; P. Seidel, 'Der Große Kurfürst in der Plastik seiner Zeit', Hohenzollern-Jahrbuch, 2, 1898, pp. 93-106; G. Galland, Hohenzollern und Oranien. Neue Beiträge zur Geschichte der niederländischen Beziehungen im 17. und 18. Jahrhundert, und Anderes, Straßburg, Heitz, 1911; H. Lademacher (ed.), Onder den Oranje boom. Niederländische Kunst und Kultur im 17. und 18. Jahrhundert an deutschen Fürstenhöfen (exh. cat.), 2 vol. Krefeld, Kaiser-Wilhelm-Museum/ Apeldoorn, Schloss Oranienburg/ Palais Het Loo, 1999/200o.

2 G. Galland, Der Große Kurfürst und Moritz von Nassau. Studien zur brandenburgischen und holländischen Kunstgeschichte, Frankfurt am Main, Verlag von Heinrich Keller, 1893, pp. 137-56; Lademacher, as at note 1, pp. 219-20 (cat. 8/16).

3 Galland, as at note 1, pp. 53-59; S. Hüneke, 'Bildhauer am Hofe des Großen Kurfürsten', in Der Große Kurfürst. Sammler, Bauherr, Mäzen (exh. cat.), Potsdam, Staatliche Schlösser und Gärten PotsdamSanssouci, 1988, pp. 118-26; R. Bartsch-Molden, Artus Quellinus' Grabmal Sparr. Der Einfluß der of the other into a success - and vice versa. The third, and not the least, protagonist was of course the royal court. It planned and paid for the project, formulated the iconographic programme and looked for skilful artists outside Berlin, artists who were on the one hand able to realize the monument in a professional way according to the highest international standards, and on the other were willing to live and work in Brandenburg's capital. The court was clear-sighted enough to recognize that local abilities were not sufficient to start such a complex and expensive venture as an over life-size bronze equestrian statue. Due to the lack of documentation it is almost impossible to separate the interaction of all three protagonists, sculptor, caster and patron, and to determine their specific part in the common task. ${ }^{73}$ But there is no question that the quality of Schlüter's design, dependent on his erudite understanding of important sculptural forerunners and the amalgamation of their poses, combined with his ability to express power, strength and liveliness in the horse, rider and slaves was finally responsible for the great esteem in which the equestrian monument in particular is held today.

Translated by Abigail Ryan-Prohaska
Niederlande auf das Grabmal in Norddeutschland zwischen 1650 und 1725, Europäische Hochschulschriften, series 28, vol. 168, Frankfurt am Main, Peter Lang, 1993.

4 T. Schieder, 'Die preußische Königskrönung von 1701 und die politische Ideengeschichte', Altpreußische Forschungen, 12, 1935, pp. 64-86; P. Baumgart, 'Ein neuer König in Europa. Interne Planung diplomatische Vorbereitung und internationale Anerkennung der Standeserhöhung des brandenburgischen Kurfürsten', in Preußen 1701. Eine europäische Geschichte (exh. cat.), Berlin, Deutsches Historisches Museum/Potsdam, Stiftung Preußische Schlösser und Gärten Berlin-Brandenburg, 2001, pp. 166-76.

5 H. Duchhardt, 'Anspruch und Architektur: Das Beispiel Berlin',
Forschungen zur Brandenburgischen und Preußischen Geschichte, N.F. 1 1991, pp. 31-52.

6 A. Geyer, Geschichte des Schlosses zu Berlin, Vol. I: Die kurfürstliche Zeit bis zum Jahre 1698, Berlin, Deutscher Kunstverlag, 1936, p. 73; Der Große Kurfürst (exh. cat.), as at note 3 , pp. 125-26, cats. IV.44-IV.57.

7 G. Hinterkeuser, Das Berliner Schloß. Der Umbau durch Andreas Schlüter, Berlin, Siedler Verlag, 2003 , pp. 31, 400-01.

8 C. C. Schramm, Historischer Schauplatz, in welchem die Merkwuerdigsten Brücken aus allen vier Teilen der Welt . . . vorgestellet und beschrieben werden, Leipzig Breitkopf, 1735, pp. 181-86; J. C. Müller and G. G. Küster, Altes und Neues Berlin, Berlin, bey Johann Peter Schmid, 1756, vol. III, pp. 2-36 Anonymous, 'Zur Geschichte des 
Kurfürstendenkmals', Der Bär, 11, 1885 , p. 688; P. Seidel, 'Das Standbild des Großen Kurfürsten in Berlin', Zeitschrift für Bauwesen, 43, 1893, col. 55-62; D. Joseph, 'Vom Denkma des Großen Kurfürsten in Berlin', Repertorium für Kunstwissenschaft, 18, 1895, pp. 380-82; H. Voß, 'Andreas Schlüters Reiterdenkmal des Großen Kurfürsten und die Beziehungen des Meisters zur italienischen und französischen Kunst', Jahrbuch der Königlich Preußischen Kunstsammlungen, 29, 1908, pp. 13764; P. Zucker, 'Plastik und Brücke', Monatshefte für Kunstwissenschaft, 13, 1920, pp. 19-27, esp. p. 21; W. Boeck, 'Schlüters Großer Kurfürst', Pantheon, 14, 1934, pp. 288-92; H. Ladendorf, Der Bildhauer und Baumeister Andreas Schlüter. Beiträge zu seiner Biographie und zur Berliner Kunstgeschichte seiner Zeit, Forschungen zur deutschen Kunstgeschichte 2, Berlin, Deutscher Verein für Kunstwissenschaft, 1935, pp. 18-23; H. Ladendorf, Andreas Schlüter, Berlin, Rembrandt-Verlag, 1937, pp. 27-47; K. Scheffler, Der Kunstbrief. Das Denkmal des Großen Kurfürsten in Berlin von Andreas Schlüter, Berlin, Gebrüder Mann, s.a. (1940); W. Kurth, 'Das Denkmal des Großen Kurfürsten von Andreas Schlüter', Was uns bewegt. Fragen der Weltanschauung. Politik, Geschichte und Kultur. Tornisterschrift des Oberkommandos der Wehrmacht für Offiziere, 1, 1943, pp. 24-26; H. Ladendorf, Andreas Schlüter. Das Denkmal des Großen Kurfürsten, Stuttgart, Reclam, 1961; I. Wirth (ed.), Die Bauwerke und Kunstdenkmäler von Berlin, Stadt und Bezirk,

Charlottenburg, Berlin, Gebrüder Mann, 1961, vol. text, pp. 485-90; U. Keller, Reitermonumente absolutistischer Fürsten. Staatstheoretische Voraussetzungen und politische Funktionen, Munich/Zurich, Schnell und Steiner, 1971, pp. 81-120; J. Tripps, 'Berlin als Rom des Nordens: das Stadtschloß im städtebaulichen Kontext', Bruckmanns Pantheon, 55, 1997, pp. 112-25, esp. pp. 113-17; C. Frank, 'Zwischen Frankreich und Preußen. Das Denkmal des Großen Kurfürsten von Andreas Schlüter im Spiegel seiner öffentlichen Rezeption', in Preußen 1701 (exh. cat.), as at note 4 , vol. essays, pp. 341-52; B. Nicolai, Andreas Schlüter. Das Reiterdenkmal des Großen Kurfürsten im Ehrenhof von Schloss Charlottenburg, Berlin, Gebrüder Mann, 2002; G. Hinterkeuser, 'Die Bronzedenkmäler von Andreas Schlüter und Johann Jacobi zwischen Kostümfrage, internationalem Prestige und Künstlerruhm', in R. Marth and M. Trusted (eds), Barocke Kunststückh. Festschrift für Christian Theuerkauff / Sculpture Studies in Honour of Christian Theuerkauff, Munich, Hirmer, 2011, pp. 94-101.
9 Ladendorf (1935), as at note 8 , pp. 17-20; R. Müller, Das Berliner Zeughaus. Die Baugeschichte, Berlin, Brandenburgisches Verlagshaus, 1994, pp. 111-23; S.-G. Gröschel, 'Kurfürst Friedrich III. von Brandenburg: Apoll und Alexander. Zur Bronzestatue Andreas Schlüters', Pegasus, 2, 2000, pp. 91-102.

10 Hinterkeuser, as at note 7 , pp. $97-256$.

11 W. Fijałkowski and H. Kondziela, 'Die künstlerische Tätigkeit Andreas Schlüters in Polen', in Michelangelo heute. Wissenschaftliche Zeitschrift der Humboldt-Universität zu Berlin, Sonderband 1965, Anhang, pp. 267-90; Hinterkeuser, as at note 7, pp. 9-13.

12 J. Starzyński, 'Wilanów. Dzieje budowy pałacu za Jana III', Studia do dziejów sztuki w Polsce 5, Warsaw, 1933 (2nd edn. 1976); T. Mańkowski, 'Prace Schlütera w Wilanowie', Prace Komisji Historii Sztuki, 8, 1939/1946, pp. 151-81; W. Fijałkowski, Wnetrza Pałacu w Wilanowie, Warsaw, Państwowe Wydawnictwo Naukowe, 1977; W. Fijałkowski, Wilanów. Rezydencja króla zwycięzcy, Warsaw, Krajowa Agencja Wydawnicza, 1983; Hinterkeuser, as at note 7, pp. 13-23; G. Hinterkeuser, 'Ex oriente lux? Andreas Schlüter und der polnische Anteil am Ausbau Berlins zur Königsmetropole unter Friedrich III./I.', in M. Omilanowska and A. Straszewska (eds), Wanderungen: Künstler-Motiv-Kunstwerk-Stifter /Wędrówki: Artysta - Wzorzec Dzieło - Fundator. Beiträge der 10. Tagung des Arbeitskreises deutscher und polnischer Kunsthistoriker in Warschau, 25.-28. September 2003, Warsaw, Instytut Sztuki Polskiej Akademii Nauk, 2005, S. 27-41.

13 Starzyński, as at note 12 , p. 86 [no. XVII], p. 97; Hinterkeuser, as at note 7 , p. 22

14 Schramm, as at note 8; $R$. Borrmann, 'Die Lange Brücke (Kurfürsten-Brücke) in Berlin', Zeitschrift für Bauwesen, 44, 1894, pp. 327-44; Ladendorf (1935), as at note 8, p. 12; H. Lorenz (ed.), Berliner Baukunst der Barockzeit. Die Zeichnungen und Notizen aus dem Reisetagebuch des Architekten Christoph Pitzler (1657-1707), Berlin, Nicolai-Verlag, 1998, pp. 144-45.

15 F. Weinitz, Johann Jacobi. Der Gießer des Reiterdenkmals des Großen Kurfürsten in Berlin. Sein Leben und seine Arbeiten, Berlin, Karl Curtius, 1914; Ladendorf (1935), as at note 8,

p. 15 , pp. 118-22, no. I, 94-97.

16 A. Magnien, 'Les bronzes "Keller", Bulletin de la Société de l'Histoire de l'Art Français, 1996, pp. 37-63.

17 Keller, as at note 8, pp. $47-80$; M. Martin, Les monuments équestres du Louis XIV, une grande entreprise de propagande monarchique, Paris, Picard, 1986, pp. 92-117; Hendrik Ziegler, Der Sonnenkönig und seine
Feinde. Die Bildpropaganda Ludwigs XIV. in der Kritik, Petersburg, Michael Imhof, 2010, pp. 116-24.

18 M. F. Rabe, Das Grabmal des Kurfürsten Johannes Cicero von Brandenburg in der Domkirche zu Berlin, ein Kunstwerk von Peter Vischer dem Aelteren in Nürnberg, beendigt von seinem Sohne Johannes Vischer, Berlin, C. G. Lüderitz, 1843; F. Kugler, 'Über das eherne Denkmal des Kurfürsten Johann Cicero in der Domkirche zu Berlin und dessen Beziehungen zu Peter Vischer', Deutsches Kunstblatt, 2, 1851, pp. 36870; R. Borrmann, Die Bau- und Kunstdenkmäler von Berlin, Berlin, Julius Springer, 1893, p. 164.

19 Ladendorf (1935), as at note 8 , pp. 13f, 33-35; Müller, as at note 9 , pp. 31-38, 126-32; I. Dautel, Andreas Schlüter und das Zeughaus in Berlin Petersburg, Michael Imhof, 2001.

20 Ladendorf (1935), as at note 8, pp. 55-56, 6o-65; M. Engel, 'Der Dom im 18. Jahrhundert - eine Standortfrage', in Der Berliner Dom. Zur Geschichte und Gegenwart der Oberpfarr- und Domkirche zu Berlin, Berlin, JOVIS, 2001, pp. 11-21; H.-J. Kuke, Jean de Bodt. Architekt und Ingenieur im Zeitalter des Barock, Worms, Wernersche Verlagsgesellschaft, 2002, pp. 72-83

21 Kuke, as at note 20 , pp. 67-71.

22 G. Peschken, Das königliche Schloß zu Berlin. Vol. 2: Die Baugeschichte von 1701 bis 1706. Berlin/Munich, Deutscher Kunstverlag, 1998, pp. 3-25, 83-127, 205-10; Hinterkeuser, as at note 7 . pp. 231-56.

23 G. Brockmann, Die Medaillen der Kurfürsten und Könige von Brandenburg-Preußen. Vol. 1: Die Medaillen Joachim I. - Friedrich Wilhelm I. 1499-1740, Cologne, Brockmann, 1994, pp. 220-21.

24 B. Adam, 'Henry Reetz. Vom Architekten im Berlin der Schlüterzeit zum Hofbaumeister in Hannover', in Preußen 1701 (exh. cat.), as at note 4 , pp. 289-96.

25 C. H. von Heinecken and A. Humbert, Nachrichten von Künstlern und Kunst-Sachen, Leipzig, J. P. Kraus, 1768, p. 81; F. Nicolai, Beschreibung der Königlichen Residenzstädte Berlin und Potsdam, aller daselbst befindlicher Merkwürdigkeiten, und der umliegenden Gegend, Berlin, Friedrich Nicolai, 1786, p. 69; F. Nicolai, Nachricht von den Baumeistern, Bildhauern, Kupferstechern, Malern, Stukkaturen und andern Künstlern, Berlin/Stettin, 1786, p. 104; Ladendorf (1935), as at note 8, pp. 12-13.

26 L. Beger, Thesaurus Brandenburgicus, vol. 1, Cölln/ Spree, Ulrich Liebpert, 1696, p. 169: 'Equestrem dico FRIDERICI III Electoris undiquaque Gloriosissimi, STATUAM, qui medium juxta Pontem, digno tantâ Majestate Genio fulget, Diis quasi præpositus, qui omnia Deorum decorat sublimi virtutum

jubare adæquat.'; W. E. Tentzel, Monatliche Unterredungen Einiger Guten Freunde Von Allerhand Büchern und andern annehmlichen Geschichten. Allen Liebhabern Der Curiositäten Zur Ergötzlichkeit und Nachsinnen (Monthly discussions of several good friends on sundry books and other pleasant stories. For the enjoyment and contemplation of all lovers of curiosities), Leipzig, Johann Friedrich Gleditsch, 1696, p. 669: 'Vorn an ist zu sehen die schöne neue Brücke zu Berlin / davon wir auch eine Medaille vor dem Jahre im Iulio pag. 6o9. angezeiget / ietzo aber aus Herrn Begers Beschreibung kürtzlich anmercken / daß sie auf so viel steinernen Schwibbogen stehe / als die Triumph-Brücke zu Rom; daß sie mit Statuis Deorum gezieret / und darauf zu sehen Mater Deorum, Saturnus, Iupiter, Iuno, Mars, Hercules, Pallas, Diana, Apollo, Mercurius, Neptunus, Äolus; und daß über diese alle mitten an der Brücken des glorwürdigsten Erbauers Statue zu Pferd hervor rage. (At the front one can see the beautiful new bridge in Berlin / of which we also showed a medal a year before in July pag. 609 / now, however, we recently noted from Herr Beger's description / that it stands on stone suspension arches / like the Triumphal Bridge in Rome, that it is adorned with Statuis Deorum / and among them Mater Deorum, Saturnus, Iupiter, Iuno, Mars, Hercules, Pallas, Diana, Apollo, Mercurius, Neptunus, Äolus; and towering over all in the middle of the bridge, the equestrian Statue of the glorious patron)'; J. G. Schmidt, Collectionum Memorabilium Berolinensium, decas prima. Das ist derer Sammlungen Berlinischer Merck- und Denckwürdigkeiten, Berlin, Lorentz, 1728, vol. 2, pp. 5-7; Ladendorf (1935), as at note 8 , pp. 17-18; Keller, as at note 8 , pp. 91-92.

27 Ladendorf (1935), as at note 8, p. 18; J. Rasmussen (ed.), Barockplastik in Norddeutschland (exh. cat.), Hamburg, Museum für Kunst und Gewerbe, 1977, pp. 339-41; C. Theuerkauff (ed.), Die Brandenburgisch-Preußische Kunstkammer. Eine Auswahl aus den alten Beständen (exh. cat.), Berlin, Staatliche Museen Preußischer Kulturbesitz, 1981, pp. 136-37.

28 'Er wiess mir ein modell 
wax of the Elector of Brandenburg on horseback with 4 children at the corners of the pedestal, thus representing the 4 winds of the world, which were to blow his fame abroad, and underneath came the four seated cardinal virtues, with bas reliefs in between; the horse was galloping having knocked two men over, embodying unrest and war; the work was left unexecuted, for it would have cost over 50,000 thalers.)' quoted in M. Laine and B. Magnusson (eds), Nicodemus Tessin the Younger. Sources, Works, Collections. vol. 3: Travel Notes 1673-77 and 1687-88, Stockholm, Nationalmuseum, 2002, p. 141; O. Sirén, Nicodemus Tessin D.Y.'s Studieresor i Danmark, Tyskland, Holland, Frankrike och Italien,

Stockholm, Norstedt, 1914, pp. 71-72. 29 See note 26 .

30 See note 8 .

31 See note 4 .

32 Brockmann, as at note 23 , pp. 257-58.

33 The letter quoted in Frank, as at note 8 , pp. 346-47

34 Keller, as at note 8; D. A. Covi, 'The Italian Renaissance and the equestrian monument', in D.C. Ahl (ed.), Leonardo da Vinci's Sforza Monument Horse, The Art and the Engineering, Proceedings of the symposium held 18-19 April 1991, at Lafayette College and Lehigh University, and at the Dent Project Studio, Bethlehem, Lehigh University Press, 1995, pp. 40-56.

35 Zucker, as at note 8, p. 23 . Tripps, as at note 8, pp. 115-16

36 M. S. Weil, The History and Decoration of the Ponte S. Angelo, University Park, PA, Pennsylvania State University Press, 1974; Tripps, as at note 8 , pp. 114-15.

37 Tripps, as at note 8 , pp. $116-17$.

38 Beger, as at note 26 , vol. 2 ,

p. 563; Tripps, as at note 8, p. 116 .

39 P. Totti, Ritratto di Roma Antica,

Rome, 1627, pp. 197-209.

40 Tripps, as at note 8, p. 124 . no. 27.

41 T. Livius, $A b$ urbe condita, Liber

II, Cap. 10

42 See note 17.

43 Ladendorf (1935), as at note

8, p. 11.

44 Voß, as at note 8, p. 146 ; W.

Boeck, 'Neue Beiträge zu Schlüter als Bildhauer', Jahrbuch der Preußischen Kunstsammlungen, 55, 1934, pp. 24158, esp. pp. 241-46; T. Kemper, Schloss Monbijou. Von der königlichen Residenz zum Hohenzollern-Museum, Berlin, Nicolai-Verlag, 2005, p. 150.

45 Keller, as at note 8, pp. 98-99. Keller distinguishes between the side of the general and that of the head of state.

46 Voß, as at note $8, \mathrm{pp} .142-46$; For Mochi's equestrian statues, see C. Morigi Govi and M. Tirotti (eds),
I bronzi di Piacenza: rilievi e figure di Francesco Mochi dai monumenti equestrifarnesiani (exh. cat.), Bologna, Museo Civico Archeologico, 1986; M. Siemer, 'Francesco Mochi (1580-1654). Beiträge zu einer Monographie', unpub. PhD thesis, University of Würzburg, 1981 (1989), pp. 106-13 (cat. 13), 130-34 (cat. 21), 283-91.

47 It is at present undergoing examination and conservation. W. Fijałkowski, Wnętrza Pałacu w Wilanowie, Warsaw, Państwowe Wydawnictwo Naukowe, 1986, p. 66

48 Voß, as at note 8 , pp. $146-56$;

Keller, as at note 8, pp. 100-03.

49 A. E. Brinckmann

Barockskulptur, Berlin/

Neubabelsberg, Akademische

Verlagsgesellschaft Athenaion, 1921,

vol. 2, p. 372

50 H. Lorenz, 'Das barocke Berline Stadtschloß. Königliche Architektur im europäischen Kontext', in J. Kunisch (ed.), Dreihundert Jahre preußische Königskrönung.

Eine Tagungsdokumentation, Forschungen zur Brandenburgischen und Preußischen Geschichte, N.F. Supplement 6, Berlin, Duncker and Humblot, 2002, pp. 159-87; Hinterkeuser, as at note 7, pp. 262-86. 51 W. Boeck, 'Studien über Schlüter als Bildhauer', Jahrbuch der Preußischen Kunstsammlungen, 54, 1933, pp. 38-67, esp. pp. 40-41 Ladendorf (1935), as at note 8 , pp. 27-29, 104-06; M. Kühn, 'Andreas Schlüter als Bildhauer', in Rasmussen (ed.), as at note 27 , pp. 105-81, esp. pp. 161-63.

52 See note 9.

53 Ladendorf (1935), as at note 8, p. 17; G. Peschken, 'Beobachtungen zu Jean-Baptiste Broebes', in G. Hinterkeuser and J. Meiner (eds), Aspekte der Kunst und Architektur in Berlin um 1700, Potsdam, Stiftung Preußische Schlösser und Gärten Berlin-Brandenburg, 2002, pp. 151-55.

54 L. Seelig, 'Studien zu Martin van den Bogaert gen. Desjardins (1637-1694)', unpub. PhD thesis, Ludwig-Maximilians-Universität, Munich, 1980, pp. 27-204, 443-502; T. W. Gaehtgens, 'La statue de Louis XIV et son programme iconographique', in Isabelle Dubois, Alexandre Gady and Hendrik Ziegler (eds), La Place des Victoires. Histoire, architecture, société, Paris, Éditions de la Maison des Sciences de l'Homme, 2003. pp. 9-35; H. Ziegler, 'Le demi-dieu des païens. La critique contemporaine de la statue pédestre de Louis XIV', in ibid., pp. 49-65; Ziegler, as at note 17 , pp. 76-116.

55 See note 19

56 Ladendorf (1935), as at note 8, pp. 13-14; G. Peschken, 'Beobachtungen zu Schlüter', Jahrbuch der Hamburger
Kunstsammlungen, 23, 1978, pp. 65-72; Müller, as at note 9 , pp. 102-11; Dautel, as at note 19, pp. 37-77.

57 Ladendorf (1935), as at note 8, pp. 124-32, no. 122; K. Arndt, 'Denkmäler und Denkmalspläne Friedrich Wilhelms I., Königs in Preußen', in H. Krohm and C. Theuerkauff (eds), Festschrift für Peter Bloch zum 11. Juli 1990, Mainz, Von Zabern, 1990, pp. 205-13.

58 H. Ehrenberg, 'Das Denkmal Friedrichs I. von Andreas Schlüter', Sitzungsberichte der Altertumsgesellschaft Prussia, 51, 1895/1896, pp. 79-88; C. von Lorck, 'Schrötter und das Friedrichsstandbild Schlüters in Königsberg', Altpreußische Forschungen, 19, 1942, pp. 70-78.

59 F. Otten, 'Neue Quellen zur Datierung einer Wachsfigur Friedrichs I.', Zeitschrift des Deutschen Vereins für Kunstwissenschaft, 42, 1988, 2, pp. 77-81; H. Bredekamp, 'Vom Wachskörper zur Goldkrone. Die Versprechung der Effigies', in Preußen 1701 (exh. cat.), as at note 4, vol. essays, pp. 353-57; F. Otten, 'Slawische Philologie als Hilfswissenschaft', in W. Gladrow (ed.), Wortbildung, Wörterbuch und Grammatik in Geschichte und Gegenwart der Slavia. Festschrift für Erika Günther, Berliner Slawistische Arbeiten 27, Frankfurt am Main, Peter Lang, 2005, pp. 71-81.

60 Hinterkeuser, as at note 8 , pp. 98-99.

61 For the latter, see E. Benkard, Andreas Schlüter, Frankfurt am Main, Iris-Verlag, 1925, figs. 2, 3; Dautel, as at note 19, p. 40.

62 Ladendorf (1935), as at note 8, p. 124 , no. 122.

63 There is an engraved portrait of Jacobi, whereas there are no known portraits Schlüter; Hinterkeuser, as at note 8 .

64 Quoted in Schmidt, as at note 26, pp. 9-11; Preußen 1701 (exh. cat.), as at note 4, p. 234, cat. IX. 15 (C. Frank).

65 'Das erstere Modell zu dieser Statue hat der Oberbau=Director Schlüter verfertiget, und ist hiernechst durch den berühmten Johann Jacobi, aus Hamburg in Hessen gebürtig, als einem in der Giesserei=Kunst erfahrnen Manne, glücklich in einem Stücke gegossen, und wie zu sehen, nachgehends auf das zierlichste ausgearbeitet worden Se. höchstselige Königliche Majestät haben so wohl dieserhalb, als wegen anderer schönen Stücke, so derselbe gegossen, ihn eine schöne güldene Kette, woran unten eine Medaille mit dem Portrait, samt der Statua equestri und Sclaven, von dem Königl. Kupferstecher, berühmten Johann George Wolfgang auf Königliche
Kosten in Kupfer gestochen worden.' Schramm, as at note 8, p. 184 .

66 The first poem: 'In Colosseam Statuæ Equestris Molem FRIDERICI WILHELMI MAGNI, \&c. \&c., ex ære fusili a peritissimo pariter ac felicissimo tantorum operum Artifice, DOMINO IOHANNE IACOBI, in metropoli Electorali Brandenburgica d. 22. Octobr. Anni 170o, conflatam, hanc Epigrammatum bigam prolusit amica manus'. The second states: 'Quem fecit Pietas \& Belli Gloria magnum, / Reddidit hunc Audax IACOBI Dextra stupendum. / Sculpsit Alexandrum Quidam, depinxit Apelles: / Laus MAGNI summos est habuisse Viros. / Æratum fundens Te, MAGNE FRIDRICE WILHELME, / Dectra IACOBI dic mihi quanta fluit?'; both quoted in Müller and Küster, as at note 8, p. 35

67 'mit der von dem Königlichen Preußischen Directeur der Giesserey Joh. Jacobi, gegossenen Statua equestri Churfürstens Friderici Wilhelmi des Großen'; C. C. Schramm, Neues Europäisches Historisches ReiseLexikon [...], Leipzig, Johann Friedrich Gleditsch, 1744, p. 154.

68 'Dieses prächtige Denckmahl von Metall hat ein berühmter Künstler Jacobsen, aus der Schweiz gebürtig, verfertiget und es wird von allen Kennern vor ein sehr großes Kunst und Meisterwerk dieser Art gehalten'. J. Alfieri (ed.), 'Berliner Briefe vom Jahre 1731', Der Bär, 11, 1885 , p. 526.

69 Heinecken and Humbert, as at note 25 , pp. 82-83.

70 Nicolai, Nachricht . . , as at note 25, p. 93.

71 'sein Meisterstück, das ihn allein unsterblich machen könnte'; ibid., p. 104.

72 'Aber seine unsterblichen Wercke, welche Berlin verschönern, stehen da: stille Zeugen wider seiner Zeitgenossen Verläumdung, und unwidersprechliche Beweise von den Talenten eines Künstlers der ersten Größe, dem wenige gleich kommen, den noch wenigere übertreffen, und welchem mit Fortgang nachzueifern, nie das Werk eines gemeinen Kopfes seyn wird'; ibid., p. 112.

73 For questions like this, see in general V. J. Avery, 'Virtue, valor victory. The making and meaning of bronze equestrian monuments (c.1440-c.1640)', in J. Poeschke, Thomas Weigel and Britta KuschArnold (eds), Praemium Virtutis III. Reiterstandbilder von der Antike bis zum Klassizismus, Symbolische Kommunikation und gesellschaftliche Wertesysteme-Schriftenreihe des Sonderforschungsbereichs 496, vol. 22, Münster, Rhema, 2008, pp. 199-233. 